\title{
Using Social Network Analysis to Understand Actor Participation and Influence on Sustainable Management of Rugezi Wetland, Rwanda
}

\author{
H. Sylvère ${ }^{1}$, T. Emmanuel ${ }^{1}$ \\ ${ }^{1}$ University of Rwanda, College of Science and Technology, School of Science, Department of Geography, \\ Huye Town, Rwanda \\ hatesing1580@gmail.com, twarabamenye@yahoo.com
}

\begin{abstract}
Wetlands provide essential goods and services to sustain human well-being. Sustainable management of wetland is complex due competing interests and require the participation of different actors. However, there is little attention on systematic analysis of actor participation in wetland management. This paper uses Social Network Analysis (SNA) approach to analyse how actors with different interests, resources, and perceptions participate in governance arenas to influence the management of Rugezi Wetland. SNA centrality scores show that government organisations and one NGO HELPAGE occupy central positions in the network whereas Community Based Organisations occupy peripheral positions. Mann-Witney U Test shows that these central actors are able to advance their agenda incorporated in perceptions and interests on erosion control, decentralisation and local economic development, issues of illegal use of resources and lack of funds to implement livelihoods opportunities for households which depend on the use of the wetland resources. Peripheral actors advocate issues of compensation and land grabbing from buffer zone establishment and wetland resources uses for livelihoods, but are unable to influence the central actors's agenda. SNA E-I Index reveals that government organisations are more cohesive and able to form strong ties with donors to advance their agenda through political authority resource than NGOs and CBOs. In contrast, peripheral actors, mainly CBOs are less cohesive and more tied to NGOs and local government organisations through labour provision resource in the implementation of interventions. There is a trade-off between level participation and influence among actors that can be addressed through the establishment of a coordination body able to reduce the influence of state organisations and permit CBOs and NGOs to access to different resources such as funds and expertise.
\end{abstract}

Keywords: Actor participation, Centrality Scores, E-I index, Governance arenas, Social Network Analysis, Sustainable Wetland Management 


\section{INTRODUCTION}

Wetlands provide vital ecosystem services including secure drinking water, irrigation, biodiversity, fisheries and flood protection (Ostrovskaya et al. 2013). However, competing interests among users of the wetland can lead to the degradation of habitats and diminishing of services offered by wetlands. Sustainable wetland management is centred on the participation of state and non state actors who bring diverse knowledge, interests, value and perceptions in the arenas related to wetland planning and management (Pimbert 2004). However, such diversity of actors creates complexity in prioritising the planning and implementation of formal and informal use of wetland because more influential actors impose their agenda (Lubell, Robins, and Wang 2014). The understanding of this level of influence requires a system analysis that captures how level of participation of various actors and their position influence the management of wetlands.

Systematic tools such as Social Network Analysis (SNA) have proven the capacity to assess how actors position and interact among themselves to influence ecosystems management by advocating their agenda in the planning and implementation of wetland management (Bodin and Crona, 2009). SNA provides a structured means to quantitatively describe and analyse the extent to which diverse actors with multiple attributes engage in complex interactions that foster sustainable resources management.

In Rwanda, the principle of sustainable use and management of wetlands has been brought on forefront with the designation of Rugezi Wetland as Ramsar site in 2006 (REMA, 2011). In this regard, the management of this wetland has drawn the participation of state and non state actors in rehabilitation of the wetland and its catchment, and planning and implementing livelihoods initiatives for local population. However, the sustainability of these initiatives remains a challenge. Little information exists on how relationships between actor's resources, perceptions and interests of actors and their level of participation in governance arenas can influence sustainable management of Rugezi Wetland.

In this paper, we use SNA approach to generate relational information linking actors to the governance arenas to reflect the level of actors' participation in governance arenas in order to guide targeted interventions in the areas of strengthening stakeholder involvements in measures related to sustainable management of Rugezi Wetland. In this regard, we analyse the positions of different actors which depend on their organisation status, resources and objectives and how they influence the management of the Rugezi Wetland. These positions may constitute opportunities and constraints for sustainable management of the Rugezi Wetland. If position of actors fosters informal relationships, they constitute opportunities for sustainable management of the wetland. Reversely, a dominance of vertical governance position of actor constitutes an obstacle as dominant and central actors are able to advance their agenda at the expenses of peripheral actors in the network. This paper bridges the information gap on how 
these positions impact on the sustainability of interventions in the management of Rugezi Wetland.

\section{CONCEPTUAL FRAMEWORK ON GOVERNANCE ARENAS AND NETWORKS}

Governance arenas are places where discussions or deliberation among stakeholders take place to reach a consensus to solve conflicts (Connelly, Richardson, and Miles 2006). Arenas comprise forums and project groups. Actors participate in arenas based on their attributes which include perceptions and resources (Hermans and Thissen 2009). Actor interdependencies in social networks imply that actors sharing the same attributes participate with others from different attributes groups in governance arenas to exchange resources and share responsibilities to influence the management of ecosystems (Weible and Sabatier 2005). For instance, political and financial resources may influence differently the degree of actor participation in the arenas.

The key resources that bring actors to participate in the arenas are: political authority, financial and expertise and proximity to ecosystem. When resources are concentrated in group of actors such as government agencies, they confer them the capacity to influence wetland management policy by advocating their agenda. In the sustainable management of wetland, the actor interests and objectives such as biodiversity conservation and erosion control express the actor agenda (Hermans and Thissen 2009). The analysis of this influence dynamics needs tools such as SNA to analyse how actors are positioned in networks aimed at improving the management of natural resources such as wetlands.

\subsection{Social network analysis and actors participation}

Social network analysis is used to analyse the participation and cooperation of a diversity of actors to solve a wide variety of issues related to the implementation of sustainable natural resources uses and management. It provides metrics to analyse which organisation and individual actors participate in the governance of natural resources, and what resources and agenda they bring in arenas to influence the management of natural resources (Stein, Ernstson, and Barron 2011). This metric is the centrality of actors which includes degree centrality, betweenness centrality and eigenvector centrality. Degree centrality refers to number of ties that actors share with others participating in the same arenas (Lipponen et al. 2003). This means that the most central actor is the one who participates in many arenas, and has high degree of centrality. Consequently a central actor has the ability to advance his agenda reflected by his interests and perceptions.

Cárcamo, Garay-Flühmann, and Gaymer (2014) have shown that centrality metrics need to be combined with E-I (external and internal links) index to capture how groups of actors are influential by internal and cross-boundary relationships (Parise 2007). Therefore, the influential individual or group of actors are those who establish relationships beyond their groups (boundaries). This grouping is based on the attributes such as organisational types and resources (McGrath and Krackhardt 2003). These actors exert influence in resources 
management because their agenda and resources reach out to other groups, and push the latter to abide or adopt the agenda of influential groups or actors.

\subsection{Sustainable wetland management}

The sustainability of planning and implementing wetland management measures such as biodiversity conservation, erosion control, wetland rehabilitation and sustainable uses depends on the inclusion and participation of a wide spectrum of actors (Fletcher, Kawabe, and Rewhorn 2011). SNA is suitable for wetland management because it captures how participants exchange different resources and establish relation beyond their organisational and resources boundaries (Bodin and Crona 2009). Sustainable wetland management hinges on those crossboundary relationships which are established when actors from one type of resources such as donor participate in the same arenas with ones from other resources types such as expertise (Hermans and Thissen 2009). In this regard, diverse actors participate in networks to bring new ideas, technology and resources that permit the implementation of sustainable measures. Therefore, actors become influential when they maintain strong ties with others from other groups (Cárcamo, Garay-Flühmann, and Gaymer 2014), thus contributing to sustainable wetland management. 


\section{METHODOLOGY}

\subsection{Description of the study area}

The Rugezi Wetland is located in the Northern Province of Rwanda. Its catchment spans in the Burera and Gicumbi Districts, upstream Burera and Ruhondo Lakes (Figure1). The total catchment area is $194 \mathrm{~km}^{2}$. The catchment is characterised by hills and mountains with slope attaining $35 \%$, high population density (between 552 and 477 inhabitants $/ \mathrm{km}^{2}$ ) where $85 \%$ of the population depends on agriculture (NISR 2014). All these factors contribute to the severe erosion and threaten the potential for hydropower production and lake sedimentation. High population density and associated problems have been the main threats for the sustainability of Rugezi resources.

\section{Figure 1: Location of Rugezi Wetland in Rwanda}

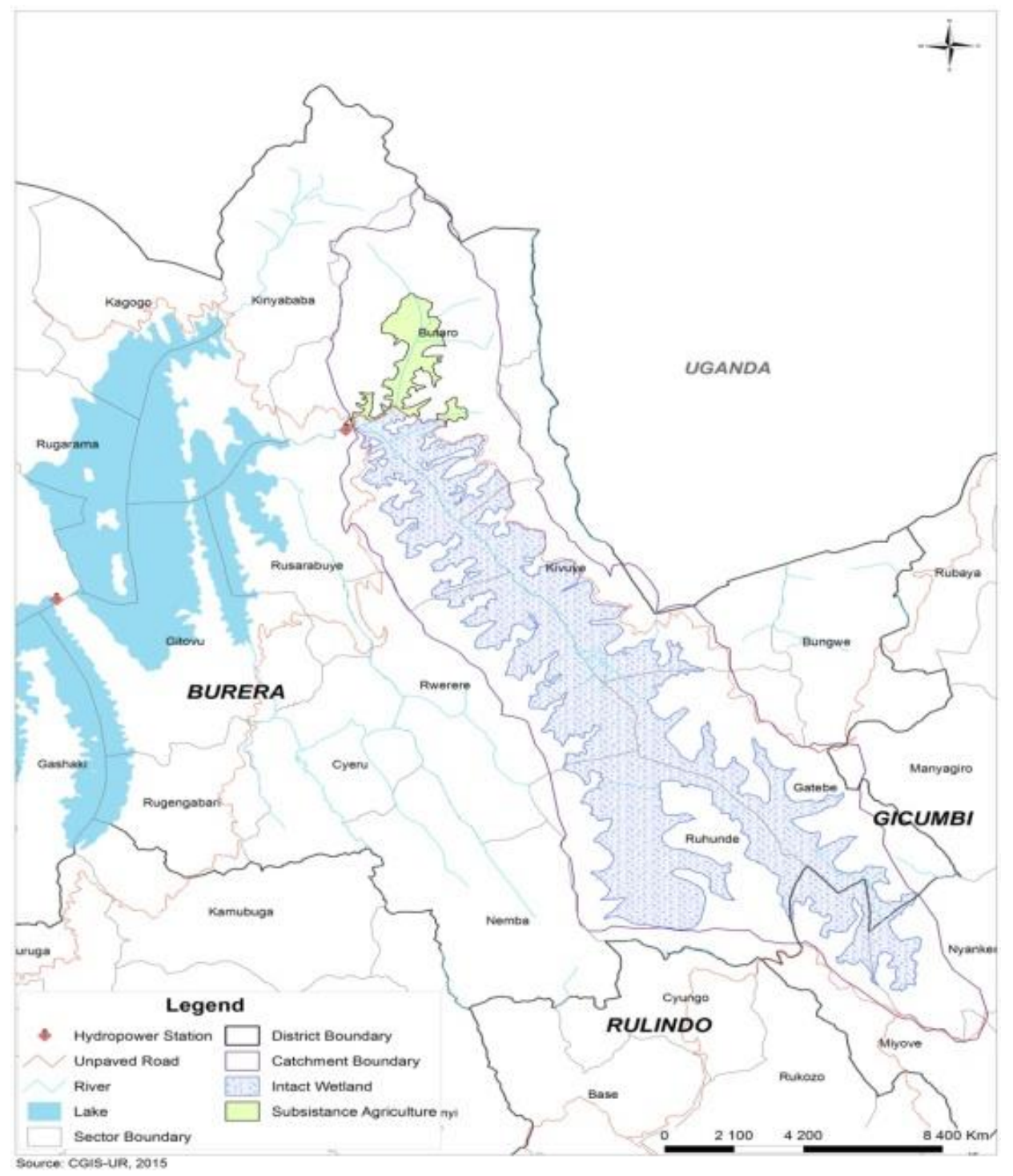

Source: CGIS-UR, 2015 
There have been many attempts to convert the wetland into agricultural land from 1960s to 2000 (Hategekimana and Twarabamenya 2007). These attempts were thwarted by the need of water for hydropower production because Ntaruka hydropower plant constructed in 1957 uses $50 \%$ of water from Rugezi Wetlands (Willetts 2008).

The conservation of Rugezi for its biodiversity interest brought more complexities. After the recognition of Rugezi wetland as Ramsar site, agriculture, fishing and plant collections were banned from the wetland, and nearby dwellers were relocated. This complexities have been complicated by sedimentation; ignorance or non enforcement of laws and regulations on wetland protection; self appropriation of the wetland for agricultural purposes; and insufficient knowledge on the functions of wetland (REMA 2009).

\subsection{Data collection}

The approach used in this paper investigated the linkages among actors attributes such as interests, perceptions, resources and institutional level, the level of participation across different arenas and interdependencies among groups using SNA. Data collection followed a two stages approach developed by Provan and Milward (2001), firstly the identification of arenas and the actor participation, and secondly actors characteristics and relationships. At arena level, the identification of arenas was based on the review of planning and project documents to identify their objectives on environment, development and natural resources management. Data sources included Rwanda Organic Law for Environmental Protection, the National Environmental Policy, the Biodiversity Policy, different ministerial instructions, and wetland planning, documents on wetland rehabilitation and conservation project proposals and the law establishing Rwanda Environmental Management Authority (REMA) as amended in 2013.

A questionnaire survey was used to collect information on actor attributes. Survey was conducted between August and November 2013. The questionnaire was addressed to one representative from each organisation that held key position such as president, coordinator of organisation or senior staff in the organisation. From 52 organisations, only 45 responded to the questionnaire. Data collected permitted to establishing a matrix linking actors and attributes with binary variables ( 1 for the presence or choice on the attributes, and 0 for the absence and non choice). For patterns of interactions among actors and arenas, interviewees were asked to choose from the list of arenas in which they participated. This allowed to construct a matrix linking the actor to arenas (Conaldi, Lomi, and Tonellato 2012). A binary code 1 was used to specify participation to the arena and 0 the absence of participation.

\subsection{Analysis}

The affiliation (participation) matrix was loaded into UCINET 6.53 Software to construct the sociograms establishing the linkages between actor and arenas (Figure 2) and to analyse the structure of networks through centrality scores. For actors and arenas, UCINET 6.53 Software permitted to calculate the following scores: normalised outdegree centrality, degree centrality, 3eigenvector centrality, and betweenness centrality (Borgatti 2005). At the actor level, 
normalised outdegree centrality was calculated to analyse the level of participation; which means the higher score for the actor means the more arenas of participation. Betweenness centrality was calculated to analyse position of actors in terms of linking peripheral actors. Eigenvector centrality was calculated for the power of actor, meaning the linkages that actor has with others who participate in many arenas.

To analyse and compare betweenness and level of participation of different actor groups, a matrix combining actor attributes was linked with results of normalised outdegree centrality into SPSS to rank actors' attributes according to the degree of participation and show differences in terms of identifying important resources, and perceptions and interests. To test this relationship, a Mann-Whitney U Test was used to analyse which actors attributes (interests, resources, perceptions) is significant or not related to the degree of actors participation, expressed in terms of normalised outdegree centrality (Table 1).

Mann-Whitney $\mathrm{U}$ test was used after testing normalised outdegree centrality data for normal distribution using Shapiro-Wilk Test $(\mathrm{P}=0.001)$. This confirmed that data were not normally distributed. As independent variable actors were divided into two groups. The first group comprised actors with affiliation or choice to interests, resources, perception and organisational type (variable1); the second group comprised actor without choice or affiliation to attributes (variable 2). This division was applied on organisational level, interests, resources, and perceptions. The outdegree centrality, as metric of actor participation in the arenas, was used as dependant variable in SPSS 20 to compare its mean rank across actor attributes.

To calculate the influence of actors, E-I index was used. It helped to calculate the ratio of internal (bonding) and external (bridging or cross- boundary) links for individual and particular groups of actors established based on organisational and resources types. E-I index ranges from -1 if all ties from actors or groups are internal to his group (bonding) and 1 if all ties from or to actor group are external (cross boundary-spanning or bridging) (Tortoriello and Krackhardt 2010). To this purpose, actors were grouped according to the attributes such as organisational (public, private, Non Government Organisations (NGOs), Community Based Organisations (CBOs), type and resources (financial resources, political authority and expertise). This helped to assess the degree of interdependencies. 


\section{RESULTS}

\subsection{Governance arenas in Rugezi Wetland}

The management of Rugezi Wetland is established around six governance arenas that connect a diversity of actors who have different objectives. A comparative analysis of arenas focusing on their objectives and outputs shows that they are guided by strategic directions for integrated management of wetland enshrined in different policies such as the 1) decentralisation and environmental policy i.e. Thematic Working Group on Environment and Natural Resources (TWG) and for Joint Action Development Forum (JADF), 2) implementation of site specific policy instruments relevant to the management of Rugezi Wetland i.e. "Projet de Development Economique Durable (PDED)", Bamboo project and Research, Monitoring and Enforcement of Rules and Regulation. Initiated and hosted by NGOs or government organisation, these arenas set up incentives for the involvement of the community who is adjacent to the wetland. The identified arenas are formal and informal, involving government organisations, civil society and community based organisations. Since Rugezi Wetland enjoys protection status based on its importance in water supply for hydropower generation and biodiversity, the Government of Rwanda has prevented the communities to exploit the wetland resources.

\subsection{Actors' attributes: perception, interests and resources among the actors}

Sustainable management of Rugezi Wetland involves a diversity of actors with different attributes. Table 1 shows that catchment erosion and poverty resulting from the banning on the wetland resources use were important perception for actors who participate in the management of the Rugezi Wetland (respective means 0.91 and 0.81). The most reported interests that motivate the actors to participate in the governance arenas were erosion control and the decentralisation policy and local economic development (respective means 0.73 and 0.42 ). The most important resources are the political authority and geographic proximity to wetland by CBOs. The latter are involved in erosion and catchment protection activities, monitoring and assessment of resources, and surveillances of illegal activities.

Table 1: Actors perceptions, interests and resources

\begin{tabular}{|l|l|c|}
\hline Perceptions, interests and resources & Mean & $\begin{array}{c}\text { Standard } \\
\text { deviation }\end{array}$ \\
\hline Non compensation and land grabbing & 0.38 & 0.49 \\
\hline Biodiversity degradation & 0.58 & 0.50 \\
\hline Illegal uses of wetland resources & 0.67 & 0.47 \\
\hline Catchment erosion & 0.91 & 0.28 \\
\hline Insufficiency of land & 0.49 & 0.50 \\
\hline Lack of funds to implement livelihoods initiatives & 0.49 & 0.49 \\
\hline $\begin{array}{l}\text { Lack of livelihoods opportunities for communities who } \\
\text { are dependent on wetland resources }\end{array}$ & 0.56 & 0.50 \\
\hline Poverty resulting from banning use of wetland resources & 0.89 & 0.31 \\
\hline Erosion control & 0.73 & 0.47 \\
\hline Resources use & 0.04 & 0.20 \\
\hline Biodiversity conservation & 0.29 & 0.45 \\
\hline
\end{tabular}




\begin{tabular}{|l|l|l|}
\hline Ecotourism & 0.09 & 0.28 \\
\hline Decentralisation and local economic development & 0.42 & 0.49 \\
\hline Geographic proximity and provision of labour & 0.49 & 0.50 \\
\hline Political authority & 0.51 & 0.50 \\
\hline Financial resources & 0.27 & 0.44 \\
\hline Expertise & 0.18 & 0.38 \\
\hline Source: Interviews
\end{tabular}

\section{3: Levels of participation by actor centrality}

Figure 2 shows the general picture of the network, and also depicts the central location of NGOs and local government organisations, whereas the peripheral position is occupied by some donors and CBOs. The centre of the network is occupied by REMA, districts and their sectors, and Help Age (HELPAGE). At the actor level, the analysis indicates the participation in the arenas is led by two organisations, Burera and Gicumbi Districts, and HELPAGE (0.25 eigenvector centrality scores) and REMA ( 0.21 eigenvector centrality scores). This is explained by the fact that they co-participate in arenas such as JADF, PDED and IMCE (Integrated Management of Critical Ecosystems).

The central role of REMA is demonstrated by its importance in establishing IMCE and participating in the high level national arena such as TWG that links national level arena with locally based arenas ((IMCE and Research Monitoring and Enforcement of Regulations (RMER)) The betweenness centrality for this organisation is 37.70. Burera and Gicumbi districts' coordination role is observed through JADF and, PDED and RMER arenas where they co-participate with sectors. In contrast, REMA participated in different arenas not only through its position as a national agency, but also through its subsidiary officers (internees) at district level. REMA is the leading actor in TWG, IMCE and RMER, JADF and PDED at district level. This was shown by REMA's betweenness centrality score. Indeed, REMA disseminates rules and regulations, and has expertise and financial resources as well.

The centrality scores of NGOs were not negligible. For instance, HELPAGE scores were respectively, 4 for degree centrality, 17.15 for betweenness centrality and 0.21 for eigenvector centrality. This NGO hosts the PDED project through which it has created and mobilised the participation of Beneficiary Management Committees. These committees, in partnership with Private Sector Organisations (PSOs) and HELPAGE, established consultation mechanisms and contracts for the management of PDED projects. HELPAGE provides the technical expertise in the PDED and IMCE arenas, and harnessed the resources of proximity to wetland which is possessed by CBOs. The latter are engaged in agro forestry activities with private sector organisations.

Another example is that of "Association Rwandaise des Ecologistes (ARECO) Rwanda Nziza" which participated in 1) Bamboo project and 2) JADF arenas. However, its betweenness centrality and eigenvector centrality are very low, respectively 2.81 and 0.09 . This organisation has also created and mobilised incentives to engage and mobilise community based 
organisations to use their physical proximity to wetland site in bamboo nursery and dissemination. However, its participation remains limited although it has created and cooperates with CBOs.

Centrality measures also showed limited participation for some State agencies and donors. For instance, Rwanda Natural Resources Authority (RNRA), a government agency in charge of land, forestry and water resources monitoring, occupies a peripheral position (3.76 for betweenness and 0.10 for Eigenvector centrality scores). The participation of donor organisations like the Swedish International Development Agency (SIDA), Department for International Development (DFID) and African Development Bank (AfDB) was limited to the TWG arena. However, centrality measures show that, the World Bank (WB) and Dutch Embassy had higher participation than other donors because they participate in arenas such as PDED, RMER and IMCE (Figure.2)

\section{Figure 2: Actors and arenas based network for Rugezi Wetland}

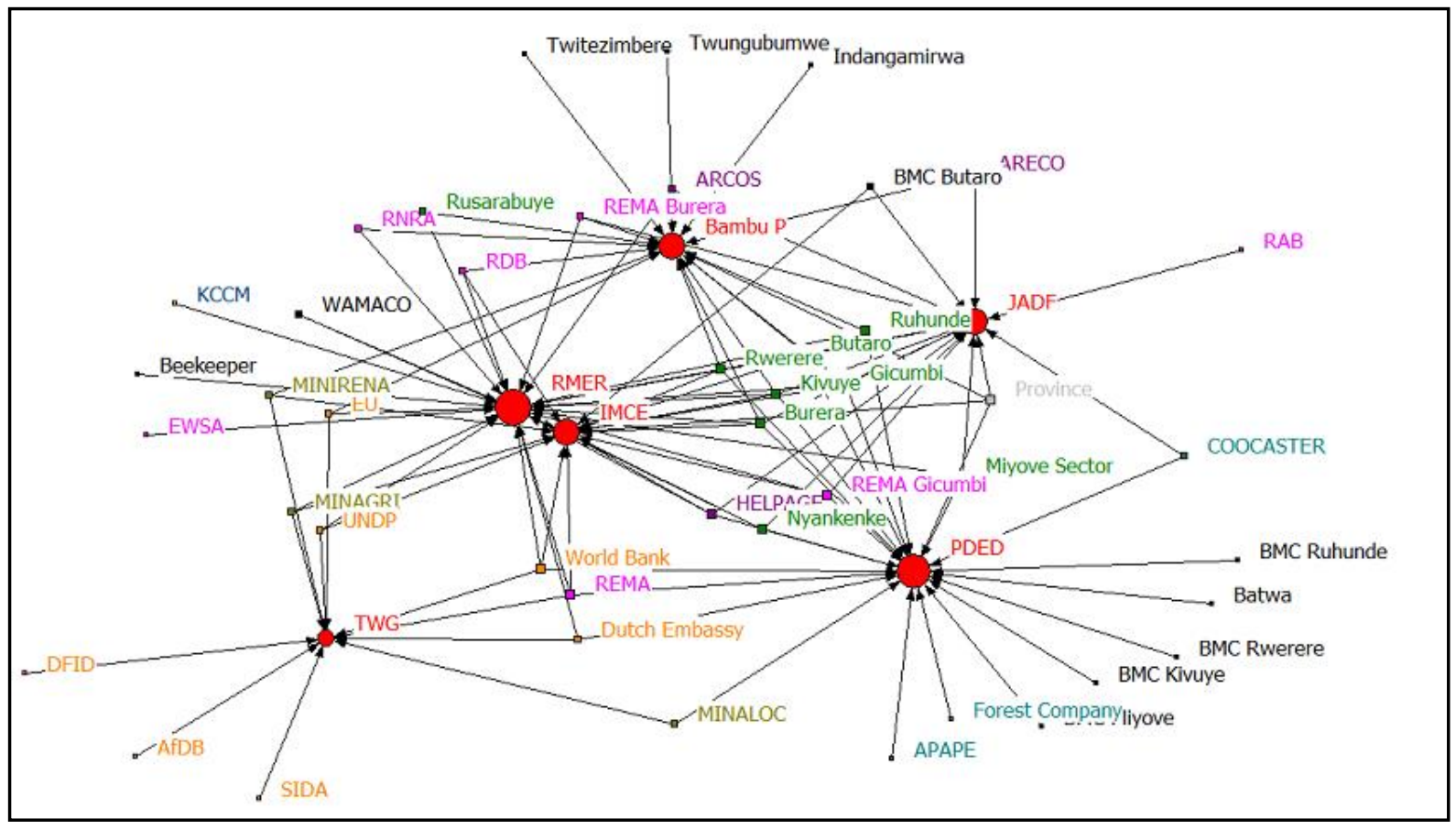

\begin{tabular}{|l} 
Legend \\
\hline \\
Arena \\
Ministry \\
Non Government organisation \\
Agency \\
Donor \\
Community Based Organisation \\
Private Sector Organisation \\
Local Government \\
Province \\
Research and education
\end{tabular}


Figure 3 provides a comparative sketch of participation of organisational groups of actor in governance arenas through centrality scores. All three measures of centrality showed that local government organisations participated more in governance arenas. PSOs, universities, the Northern Province, ministries and CBOs have lower centrality scores because they participated in few arenas.

Figure 3: Centrality by actor type

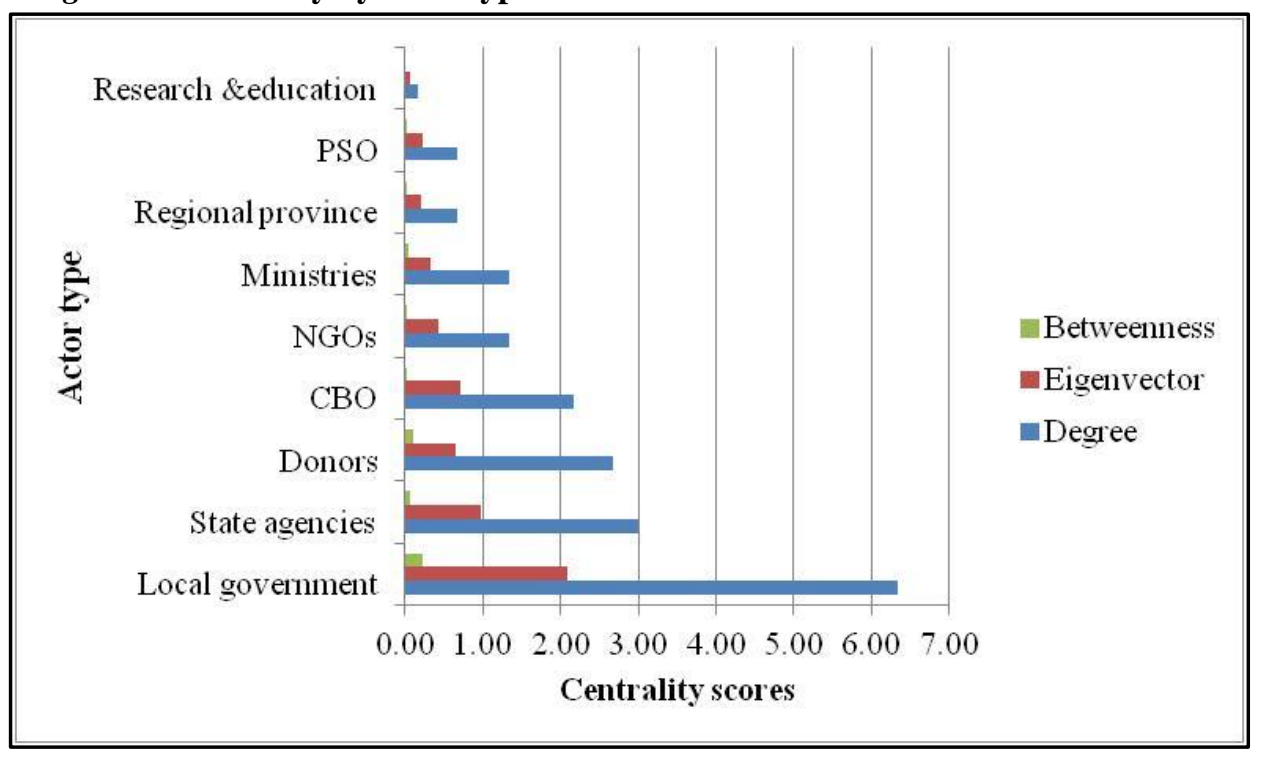

\subsection{Actors attributes by level participation in governance arenas}

There is a link between actors' attributes and the degree of participation. According to Table 2, the most relevant issues, resources and organisation types are those linked to central actors. For instance, actors which perceive catchment erosion as an issue to for the management of Rugezi Wetland have high outdegree centrality compared with other actors (Mann-Whitney U test, Mean rank 30.21 compared with 19, $p=0.000$ ). Actors which perceive illegal uses of wetland resources as a problem have also significant higher degree centrality than others with different perceptions (Mann-Whitney U test, Mean rank 27.26 compared to 13.56; $p=0.001$ ). In contrast, actors group with perception on non compensation and land grabbing as management issues had significantly lower degree centrality than other perceptions (Mann-Whitney U test, Mean rank 17. 80 compared with 27.16; $p=0.008$ ).

As of perceptions on livelihoods issues, actors group with perception on lack of funds had significant higher mean outdegree centrality than others (Mann-Whitney U test, Mean rank 34 compared to $19.96 ; p=0.000$ and 2 ). In addition, actors group with perception on poverty resulting from the banning on resources uses had higher outdegree centrality than other actors (Mann-Whitney U test, Mean rank 32 compared 18.03; $p=0.001$ ). No significant mean outdegree centrality was found for the actors groups with perception on lack of livelihoods opportunities, insufficient land and biodiversity degradation. 
Considering the organisation type, results revealed significant mean rank outdegree centrality in favour of state organisations (Mann-Whitney U test, 31.08 compared with 16.54, p=0.000). Further organisational subdivision indicated that government organisations had highly significant outdegree centrality compared with others (Mann-Whitney U test, mean rank 38.72 compared 19.07; $p=0.000$ ). Community based organisation had lower significant outdegree centrality than others (Mann-Whitney U test, mean rank 11.82 versus 26.62, $p=0.00$ ).

Taking into consideration the difference in actor interests, results firstly suggested that actors group on erosion control interest had higher significant outdegree centrality than others (MannWhitney U test, mean rank 25.79 compared to $15.33, p=0.008$ ). Secondly, the actors group on decentralisation and local economic development interest had very higher significant outdegree centrality than others (Mann-Whitney U test, mean rank 30.32 compared with17.63, $p=0.000$ ). No significant mean rank outdegree centrality was found for actors groups with wetland resources use, biodiversity conservation and ecotourism interests

Considering the resources, results confirmed that actors group with political authority resources had higher outdegree centrality than other group (Mann-Whitney U test, mean rank 29.63 vs $16.07, \mathrm{p}=0.000$ ). No significant outdegree centrality was found for proximity to wetland and labour provision, financial resources and expertise. The non significant outdegree means that actors with these interests, organisational groups, perceptions and resources have limited participation in the arenas.

Table 2: Level of actors participation based on mean normalised outdegree centrality for actors attributes

\begin{tabular}{|c|c|c|c|c|}
\hline Actor attributes & Frequencies & $\begin{array}{l}\text { Mean rank for } \\
\text { outdegree centrality }\end{array}$ & $\begin{array}{l}\text { Z } \\
\text { Value }\end{array}$ & P value \\
\hline \multicolumn{5}{|l|}{ Interests } \\
\hline $\begin{array}{l}\text { Wetland resources use interests (yes= } \\
\text { 1) }\end{array}$ & 3 & 16.80 & \multirow[t]{2}{*}{-0.84} & \multirow[t]{2}{*}{ NS } \\
\hline Other interests $($ no $=0)$ & 42 & 23.78 & & \\
\hline Erosion control (yes=1) & 33 & 25.79 & \multirow[t]{2}{*}{-2.37} & \multirow[t]{2}{*}{$0.017^{*}$} \\
\hline Other interests $($ no $=0)$ & 12 & 15.33 & & \\
\hline $\begin{array}{l}\text { Biodiversity conservation interests } \\
(y=s=1)\end{array}$ & 13 & 26.31 & \multirow[t]{2}{*}{-1.08} & \multirow[t]{2}{*}{ NS } \\
\hline Other interests $($ no $=0)$ & 32 & 21.66 & & \\
\hline Ecotourism interests (yes $=1$ ) & 4 & 34.00 & \multirow[t]{2}{*}{-1.76} & \multirow[t]{2}{*}{ NS } \\
\hline Other interests $($ no $=0)$ & 41 & 21.98 & & \\
\hline $\begin{array}{l}\text { Decentralisation and local economic } \\
\text { development }(\text { yes }=1)\end{array}$ & 19 & 30.32 & \multirow[t]{2}{*}{-3.20} & \multirow[t]{2}{*}{$0.001 * *$} \\
\hline Other interests $($ no $=0)$ & 26 & 17.65 & & \\
\hline \multicolumn{5}{|l|}{ Organisation type } \\
\hline $\begin{array}{l}\text { Community based organisations (yes } \\
=1 \text { ) }\end{array}$ & 11 & 11.83 & \multirow[t]{2}{*}{-3.26} & \multirow[t]{2}{*}{$0.001 * *$} \\
\hline Other organisations $($ no $=0)$ & 31 & 22.32 & & \\
\hline
\end{tabular}




\begin{tabular}{|c|c|c|c|c|}
\hline $\begin{array}{lll}\text { Local government } & \text { organisations( } \\
\text { yes }=1) & & \\
\end{array}$ & 9 & 38.72 & \multirow[t]{2}{*}{-4.03} & \multirow[t]{2}{*}{$0.000 * * *$} \\
\hline Other organisations $(=0)$ & 36 & 19.07 & & \\
\hline Ministries ( yes $=1)$ & 3 & 24.33 & \multirow[t]{2}{*}{-0.18} & \multirow[t]{2}{*}{ ns } \\
\hline Other organisations $($ no $=0)$ & 42 & 22.90 & & \\
\hline $\begin{array}{l}\text { Non government organisation (civil } \\
\text { society) }\end{array}$ & 3 & 27.00 & \multirow[t]{2}{*}{-0.54} & \multirow[t]{2}{*}{ ns } \\
\hline Other organisations(variable no $=0$ ) & 42 & 22.72 & & \\
\hline Agencies & 6 & 22.31 & \multirow[t]{2}{*}{-0.90} & \multirow[t]{2}{*}{ ns } \\
\hline Other organisations ( variable no $=0$ ) & 39 & 27.50 & & \\
\hline Donors & 7 & 18.36 & \multirow[t]{2}{*}{-1.02} & \multirow[t]{2}{*}{$\mathrm{ns}$} \\
\hline Other organisation(variable no $=0$ ) & 38 & 23.86 & & \\
\hline Private Sector organisations (yes $=1$ ) & 3 & 23.62 & \multirow[t]{2}{*}{-1.18} & \multirow[t]{2}{*}{ ns } \\
\hline Other organisations $($ no $=0)$ & 42 & 14.33 & & \\
\hline State organisations $($ yes $=1)$ & 20 & 31.08 & \multirow[t]{2}{*}{-3.70} & \multirow[t]{2}{*}{$0.000 * * *$} \\
\hline Non state organisations $(\mathrm{no}=0)$ & 25 & 16.54 & & \\
\hline \multicolumn{5}{|l|}{ Perceptions } \\
\hline $\begin{array}{l}\text { Non compensation and land grabbing } \\
\text { issues }\end{array}$ & 20 & 27.16 & \multirow[t]{2}{*}{-2.38} & \multirow[t]{2}{*}{$0.017 *$} \\
\hline Others $($ no $=0)$ & 25 & 17.80 & & \\
\hline Biodiversity degradation (, yes= 1$)$ & 30 & 24.87 & \multirow[t]{2}{*}{-1.35} & \multirow[t]{2}{*}{ ns } \\
\hline Others $($ no $=0)$ & 15 & 19.27 & & \\
\hline $\begin{array}{l}\text { Illegal uses of wetland resources (, } \\
\text { yes=1) }\end{array}$ & 31 & 27.26 & \multirow[t]{2}{*}{-3.25} & \multirow[t]{2}{*}{$0.001 * *$} \\
\hline Others $($ no $=0)$ & 14 & 1.57 & & \\
\hline Catchment erosion $($ yes $=1)$ & 24 & 30.21 & \multirow[t]{2}{*}{-3.95} & \multirow[t]{2}{*}{$0.000 * * *$} \\
\hline Others $($ no $=0)$ & 21 & 14.76 & & \\
\hline Insufficient land ( yes= 1) & 25 & 24.45 & \multirow[t]{2}{*}{-0.66} & \multirow[t]{2}{*}{ ns } \\
\hline Other(no $=0)$ & 20 & 21.84 & & \\
\hline $\begin{array}{l}\text { Lack of funds to implement } \\
\text { livelihoods initiatives(yes=1) }\end{array}$ & 26 & 14.98 & \multirow[t]{2}{*}{-4.82} & \multirow[t]{2}{*}{$0.000 * * *$} \\
\hline Others $($ variable no $=0)$ & 19 & 34.00 & & \\
\hline $\begin{array}{l}\text { Lack of livelihoods opportunities } \\
(\text { yes }=1)\end{array}$ & 23 & 22.05 & -0.47 & ns \\
\hline Others $($ no $=0)$ & 22 & 23.91 & & \\
\hline $\begin{array}{l}\text { Poverty from the ban on use of } \\
\text { wetland resources (yes }=1 \text { ) }\end{array}$ & 29 & 32.00 & -3.43 & $0.000 * * *$ \\
\hline Other $($ no $=0)$ & 16 & 18.03 & & \\
\hline Resources & & & & \\
\hline $\begin{array}{llll}\begin{array}{l}\text { Proximity } \\
(y e s=1)\end{array} & \text { resources } & \text { to wetland } \\
\end{array}$ & 22 & 23.43 & -0.22 & ns \\
\hline Others $($ no $=0)$ & 23 & 22.55 & & \\
\hline Political authority resources (yes $=1$ ) & 23 & 29.63 & -3.47 & $0.000 * * *$ \\
\hline Others $($ no $=0)$ & 22 & 16.07 & & \\
\hline Financial resources $($ yes $=1)$ & 12 & 20.33 & -0.82 & $\mathrm{~ns}$ \\
\hline Others $($ no $=0)$ & 33 & 23.97 & & \\
\hline Expertise & 8 & 22.53 & -0.52 & $\mathrm{~ns}$ \\
\hline Others & 37 & 25.19 & & \\
\hline
\end{tabular}




\subsection{Actor influence through bridging interactions by group of actors}

The average E-I index according to groupings of actors by organisational groups the average is of 0.71.This index means that there is existence of a high cooperation types between organisations. Table 2 shows that regional, research and education, NGOs, ministries, private sector organisations, agencies and local government organisations have high E-I. Results for regional and local research and educations organisations need to be interpreted with caution, because these organisations do not have pairs in their own groups. The second category of organisation to have high E-I index are NGOs and ministries (0.86). These indexes explain that NGOs plays a cross-boundary role linking different categories of actors at local level while ministries play the same role at national level.

Table 3: Bridging scores and E-I index according to groupings of actors by organisation types

\begin{tabular}{|l|l|l|l|c|}
\hline Type & Internal & External & Total & E-I \\
\hline CBOs & 46 & 224 & 270 & 0.65 \\
\hline Agencies & 22 & 151 & 173 & 0.74 \\
\hline NGOs & 6 & 85 & 91 & 0.86 \\
\hline Ministry & 6 & 84 & 90 & 0.86 \\
\hline Private sector & 14 & 125 & 139 & 0.79 \\
\hline Local government & 56 & 258 & 314 & 0.64 \\
\hline Regional & 0 & 38 & 38 & 1 \\
\hline Donors & 30 & 111 & 141 & 0.57 \\
\hline Research and education & 0 & 24 & 24 & 1 \\
\hline
\end{tabular}

The density of bridging relations shows the importance of local government organisation in terms of bridging with other groups. Table 3 indicates that CBOs, agencies, NGOs, ministries, the province, and research organisations cooperated with local government organisations at rates ranging from 0.90 to 1 . Communities based organisations cooperated better with local government organisations (0.90), NGO (0.50) and private organisations (0.53). Agencies work better with NGOs, local government organisation, the province and research and education organisations. PSOs were sought for cooperation by NGOs (0.65), local government organisations (0.97), the province and research and organisation. Ministries were chosen for cooperation by local government organisations (0.95). Donors cooperate more with ministries; $100 \%$ of ties from donors were directed to ministries (1), because the interaction took place in TWG arena in which groups concerned ministries and donors participated.

Table 3: Bridging score and EI index according to groupings of actors by organisation types

\begin{tabular}{|l|l|c|c|c|c|c|c|c|c|}
\hline Type & CBO & Agency & NGO & Min & PS & LG & Reg & Donor & R\&E \\
\hline CBO & 0.34 & 0.47 & 0.50 & 0.44 & 0.53 & $\mathbf{0 . 9 0}$ & $\mathbf{0 . 9 1}$ & 0.31 & 0.25 \\
\hline Agency & & $\mathbf{0 . 7 3}$ & $\mathbf{0 . 8 8}$ & 0.55 & 0.53 & 0.97 & $\mathbf{0 . 8 3}$ & 0.50 & $\mathbf{0 . 8 3}$ \\
\hline NGOs & & & 1 & 0.55 & $\mathbf{0 . 6 6}$ & 1 & 1 & 0.38 & $\mathbf{0 . 6 6}$ \\
\hline Ministry & & & & 1 & 0.53 & $\mathbf{0 . 9 5}$ & 1 & 1 & 0.33 \\
\hline Private Sector & & & & & $\mathbf{0 . 7 0}$ & $\mathbf{0 . 9 2}$ & 1 & 0.50 & 0.40 \\
\hline $\begin{array}{l}\text { Local } \\
\text { Government }\end{array}$ & & & & & & 1 & 1 & 0.50 & 1 \\
\hline Regional & & & & & & & 0 & 0.50 & 0 \\
\hline Donor & & & & & & & & 1 & 0.50 \\
\hline
\end{tabular}




\begin{tabular}{|l|l|l|l|l|l|l|l|l|l|}
\hline Research and Education & & & & & & & & & 0 \\
\hline
\end{tabular}

The E-I average index for resources exchange grouping is 0.334 . This index indicates the existence of a considerable number of organisations who cooperate with those with different resources. Table 4 shows that actors with highest E-I are those with expertise (0.72) that means they highly maintain interdependent relationships with those with different resources. The second group is composed of actors with proximity to wetland and labour provisions (0.646). Actors with political authority resources have lowest E-I Index (0.04). This means that both internal and external ties in the exchange of resources with this group are high.

Table 4: Bridging score and I-I index according to groupings of actors by resources

\begin{tabular}{|l|l|l|l|l|}
\hline Types & Internal & External & Total & E-I \\
\hline $\begin{array}{l}\text { Proximity to wetland and } \\
\text { provision of labours }\end{array}$ & 52 & 294 & 294 & 0.64 \\
\hline Political authority & 310 & 342 & 652 & 0.04 \\
\hline Expertise & 22 & 140 & 162 & 0.72 \\
\hline Financial resources & 42 & 130 & 172 & 0.51 \\
\hline
\end{tabular}

The density of bridging relations on resources exchange shows a different brokerage role for organisational groups. The reading of Table 5 from row-wise position shows that group of actors with proximity to wetland resource highly cooperate with political authority actors group and expertise group. Political authority group works better with those with: 1) proximity to wetland and labour provision, 2) expertise, 3) financial resources. Actors with expertise cooperate better with proximity to wetland, political authority and less with donors. Actors with financial resources chose those with political resource for cooperation. A diagonal reading of table 5 explains that the within group cooperation is very high, especially for financial resources, political authority and expertise groups. Intra-cooperation for proximity and labour provision group is low (0.33). Both E-I index, and density scores translate the bridging of actors and the likelihood of actors to meet in the same arenas and exert their influence. For instance, density of relationships across organisation types shows that donors maintains strong ties with ministries, $50 \%$ far from local government organisations and 38\% from NGOs.

Table 5: density of relationships within and cross boundary ties according to grouping of actors by resources

\begin{tabular}{|l|c|c|c|c|}
\hline Resources & Proximity & $\begin{array}{c}\text { Political } \\
\text { authority }\end{array}$ & Expertise & $\begin{array}{c}\text { Financial } \\
\text { resources }\end{array}$ \\
\hline Proximity & 0.33 & $\mathbf{0 . 6 9}$ & $\mathbf{0 . 5 0}$ & $\mathbf{0 . 3 4}$ \\
\hline Political authority & & 0.90 & $\mathbf{0 . 7 5}$ & $\mathbf{0 . 6 3}$ \\
\hline Expertise & & & 0.73 & $\mathbf{0 . 3 5}$ \\
\hline Financial & & & & $\mathbf{1}$ \\
\hline
\end{tabular}




\section{DISCUSSION}

The strength of SNA is demonstrated by the interdependency of its metrics with actors' participation assessment criteria such as perceptions, interests and resources. Compared with approaches which assess actor's participation using expert ranking, influence matrices and Venn diagram, SNA appears objective (Prell et al. 2009), However, this objectivity is compromised by the lack of providing actors with the opportunities to interpret SNA metrics by allowing them to self-assess their level of participation.

By linking actors' attributes and SNA metrics (scores), results confer significant attributes to state organisations such as REMA and local decentralised entities (districts and sectors) that hold central positions in the network. These state organisations managed to influence the conservation and restoration agenda (Bodin and Crona 2009).That is why the Rugezi Wetland management has privileged strict protection against illegal uses of wetland resources by local communities, and is facing the problem of lack of funds to implement livelihoods opportunities, and poverty from ban on wetland resources and erosion control. Livelihoods and poverty reduction actions such as provision of new iron sheets to evicted families, supply of fertilisers, agro-forestry and construction of terraces and bamboos planting were integrated in both IMCE and Bambu (bamboo) arenas.

E-I index results offer a good indicator of actor influence by showing high cross boundary relationships between donors, agencies, ministries and local government organisations. This cooperation is interpreted by Lubell et al. (2014) as vertical influence and prone to sectoral fragmentation and maintenance of the policy agenda fostered by governance organisations. However, the influence other actors groups such as NGOs and private sector is not negligible in supporting erosion control and livelihoods activities. Only CBOs have limited influence as show by centrality scores. Their participation was limited by the lack of opportunities to engage with donors and national level state organisations in the same arenas. Their peripheral position does not give CBOs the opportunities to advance their agenda embodied in perceptions such as use of wetland resources and non compensation and land grabbing. In regards, centrality scores for central actors (state organisation) support provisions in land law (law No08/2005 of 14/07/2005) which stipulate that wetlands are state property from which eviction of local uses for public interests cannot be compensated (GoR 2005).

In the same vein, the findings confirm that low level involvement of local actors has contributed to non consideration of compensation claim after agricultural eviction. State actors who maintain central position and privileged relations with donors and NGOs uses environmental laws which recognise wetlands as state properties in which eviction cannot be compensated. The only resource that allows local actors participation is the provision of labour in erosion control works. According to Prell et al. (2009), successful management of the wetland will depend on more tie formation with these actors through inclusive dialogue which will integrated their claims and interests in future wetland management. 
Good cross boundary cooperation existed between NGOs and local government organisations as shown by E-I index. The influence of these NGOS is limited to technical expertise in projects that support the empowerment and engagement of CBOs in the implementation of sustainable initiatives: agro-forestry, erosion control in the Rugezi Catchment, and poverty reduction. The influence on resources attributes offered by E-I index shows good ties between expertise, political authority and proximity and labour provision group (respectively", 75\% and 50\%). These informal ties counterbalance to a small extent the influence of state organisations as they bring the participation of CBOs in Rugezi Wetland Management. The role of these informal relationships is to advance sustainable management of natural resources (Hahn et al. 2006). These informal ties, spearheaded by NGOs, strengthened local institutions and supported the capacity building on wetland ecosystems and their resources (World Bank 2008).

Overall, this paper is the first to apply SNA approach in wetland management, especially in a developing country by showing not only levels of participation but also the influence of actors through cross-boundary relationships. It has therefore provided insights on the influence of NGOs through their steering role. NGOs created local institutions and mobilised them to participate using their local resources. This steering has little implication on wetland policy because of the peripheral integration of these CBOs in the network. For sustainable wetland management, the steering roles of NGOs should be institutionalised to allow the participation of CBOs in joint decision making.

\section{CONCLUSION}

To these findings, we argue that sustainable management of Rugezi Wetland would depend on the strengthening of informal relationships between CBOS, donors and NGOs and local government organisations. This may be achieved if they are permitted to access to funding so as they participate in the same arenas at the same level as local government organisations and NGOs (for instance the JADF). This will help them to effectively engage in initiatives aimed to reduce community dependency on the uses of the wetland resources, maintain erosion control infrastructures and control illegal use of resources. For instance, Watershed Management Committee (WAMACO) which has been created through the IMCE project to control illegal use of wetland resources does not fully undertake its mandate due to lack of financial resources. WAMACO has limited capacity to generating funds by liaising with NGOs such as ARCOs and HELPAGE. A close examination on its centrality and network diagram shows its non connection from arenas such as Bamboo project and PDED.

As policy proposal, we suggest that sustainable management of Rugezi Wetland would depend on enhanced engagement of CBOs and their closer ties among themselves, donors and NGOs. This will counterbalance the influence of political organisations (ministries, agencies and local government organisations). It will also reduce the burden of local government organisations by reducing their coordination in the management of Rugezi Wetland. In the same vein the reduction of the distance of donors to CBOs in the framework of the decentralisation policy is the key to participation in sustainable management of Rugezi at the local level. For this reason, 
an independent coordination body with access to diverse resources is created to foster equal participation of all actors from different organisational types.

More targeted actions will focus on monitoring illegal uses of wetland resources, erosion control and poverty reduction. The perceptions on these issues have shown high significance as they are linked to actors with high centrality score. Institutionally, these actions can focus on the involvement of communities who are vulnerable from ban on wetland resources through their inclusion in the arenas which they co-participate with donors to influence decision making related to planning and management of the Rugezi Wetland. 


\section{REFERENCES}

Bodin, Ö. and B.I. Crona. 2009. The role of social networks in natural resource governance: What relational patterns make a difference? Global environmental change 19:366-374.

Borgatti, S.P. 2005. Centrality and network flow. Social networks 27:55-71.

Cárcamo, P.F.; R. Garay-Flühmann; and C.F. Gaymer. 2014. Collaboration and knowledge networks in coastal resources management: How critical stakeholders interact for multiple-use marine protected area implementation. Ocean \& Coastal Management 91:5-16.

Carlsson, L. and F. Berkes. 2005. Co-management: concepts and methodological implications. Journal of environmental management 75:65-76.

Conaldi, G.; A. Lomi; and M. Tonellato. 2012. Dynamic Models of Affiliation and the Network Structure of Problem Solving in an Open Source Software Project. Organizational Research Methods 15:385-412.

Connelly, S.; T. Richardson; and T. Miles. 2006. Situated legitimacy: deliberative arenas and the new rural governance. Journal of Rural studies 22:267-277.

Fletcher, S.; M. Kawabe; and S. Rewhorn. 2011. Wetland conservation and sustainable coastal governance in Japan and England. Marine pollution bulletin 62:956-962

GoR (2005). Organic Law determining the use and management of land in Rwanda. In, $N^{\circ}$ 08/2005 of 14/07/2005: Official Gazette of the Republic of Rwanda Year 44, Number 18

Hahn, T.; P. Olsson; C. Folke; and K. Johansson. 2006. Trust-building, Knowledge Generation and Organizational Innovations: The Role of a Bridging Organization for Adaptive Comanagement of a Wetland Landscape around Kristianstad, Sweden. Human Ecology 34:573-592.

Hategekimana, S. and E. Twarabamenya. 2007. The impact of wetlands degradation on water resources management in Rwanda: the case of Rugezi Marsh. In Proceedings of the 5th International Symposium on Hydrology, 7: Citeseer.

Hermans, L.M. and W.A. Thissen. 2009. Actor analysis methods and their use for public policy analysts. European Journal of Operational Research 196:808-818.

Lipponen, L.; M. Rahikainen; J. Lallimo; and K. Hakkarainen. 2003. Patterns of participation and discourse in elementary students' computer-supported collaborative learning. Learning and Instruction 13:487-509.

Lubell, M.; G. Robins; and P. Wang. 2014. Network structure and institutional complexity in an ecology of water management games. Ecology and Society 19.

McGrath, C. and D. Krackhardt. 2003. Network conditions for organizational change. The Journal of Applied Behavioral Science 39:324-336.

NISR. 2014. Thematic report: population size, structure and distribution. Kigali: National Institute of Statistics of Rwanda.

Ostrovskaya, E.; W. Douven; K. Schwartz; B. Pataki; P. Mukuyu; and R. Kaggwa. 2013. Capacity for sustainable management of wetlands: Lessons from the WETwin project. Environmental Science \& Policy 34:128-137. 
Parise, S. 2007. Knowledge Management and Human Resource Development: An Application in Social Network Analysis Methods. Advances in Developing Human Resources 9:359-383.

Pimbert, M. 2004. Institutionalising participation and people-centered processes in natural resource management. IIED.

Prell, C.; K. Hubacek; and M. Reed. 2009. Stakeholder Analysis and Social Network Analysis in Natural Resource Management. Society \& Natural Resources 22:501-518.

Provan, K.G. and H.B. Milward. 2001. Do networks really work? A framework for evaluating public-sector organizational networks. Public Administration Review 61:414-423.

REMA. 2009. Plan d'aménagement du bassin versant et plans de gestion a base communautaire du Marais de Rugezi, Volume 4. Kigali: HELPAGE. 2011. Environmental and social management framework (ESMF) for Rwanda under LVEMP II, 183. Kigali: Rwanda Environmental Management Authority.

Stein, C.; H. Ernstson; and J. Barron. 2011. A social network approach to analyzing water governance: The case of the Mkindo catchment, Tanzania. Physics and Chemistry of the Earth, Parts $A / B / C$ 36:1085-1092.

Tortoriello, M. and D. Krackhardt. 2010. Activating cross-boundary knowledge: The role of Simmelian ties in the generation of innovations. Academy of Management Journal 53:167-181.

Weible, C.M. and P.A. Sabatier. 2005. Comparing Policy Networks: Marine Protected Areas in California. Policy Studies Journal 33:181-201.

Willetts, E. 2008. Watershed Payments for Ecosystem Services and Climate Change Adaptation; Case Study on Rugezi Wetlands, Rwanda.

World, Bank. 2008. International trade and climate change : economic, legal, and institutional perspectives. Washington D.C.: World Bank 